\title{
RADIOCARBON AGES OF BEACH ROCKS AND LATE HOLOCENE SEA-LEVEL CHANGES IN THE SOUTHERN PART OF THE NANSEI ISLANDS, SOUTHWEST OF JAPAN
}

\author{
Kunio Omoto \\ Department of Geography, College of Humanities and Sciences, Nihon University, 25-40, 3 Chome, Sakurajosui, \\ Setagaya-ku, Tokyo 156-8550, Japan. Email: omoto@chs.nihon-u.ac.jp.
}

\begin{abstract}
Beach rock is a good indicator of the past sea levels, as it is considered to have been formed within the range of intertidal zone. Radiocarbon dates of beach rocks collected from Iriomote Island, Ishigaki Island, and Miyako Island, in the southern part of the Nansei Islands, indicate that the beach rocks were formed between around $4000 \mathrm{BP}$ and $400 \mathrm{BP}$. Late Holocene sea-level changes were revealed based on the elevations and ${ }^{14} \mathrm{C}$ dates of the beach rocks. The results indicate that the sea level was similar to the present one for at least the past $4000 \mathrm{BP}$. Isotopic fractionations $\left(\delta^{13} \mathrm{C}\right)$ of the beach rocks were between $+9.40 \%$ and $-0.08 \%$, suggesting a different origin for calcium carbonate.
\end{abstract}

\section{INTRODUCTION}

Nansei Islands (Ryukyu Retto) form an island arc, situated between Kyusyu and Taiwan. The arc extends about $1200 \mathrm{~km}$ parallel to the eastern edge of the Eurasian Plate. Iriomote Island, Ishigaki Island, and Miyako Island are situated in the southern part (Figure 1). These islands are subject to the influence of the Kuro Shio, which derives its origin from North Equatorial Current (warm currents), forming many fringing reefs, and sheltering most of the shores of the islands from strong wave erosion. The average maximum spring tide in the surveyed area is $1.3 \mathrm{~m}$ at Ishigaki Island.

The geology of the islands consists of the Paleozoic rocks, metamorphic rocks, volcanic rocks, the Pliocene sedimentary rocks, and Quaternary coral limestone. The coastal geomorphology is characterized most often by rocky coasts, but in other places by sandy beaches, in which a small scale of coastal plains develop. On the sandy beaches, beach rocks are observed frequently within the range of the intertidal zone where the beach sediments were cemented by calcium carbonate. Therefore they are not only good indicators which show the past sea levels, but also good sample material for radiocarbon dating.

In order to determine the formative ages of beach rocks and to reconstruct the Late Holocene sealevel changes in the southern part of the Nansei Islands, 41 beach rock samples were collected from Iriomote, Ishigaki, and Miyako Islands by the author. Elevations of each sampling site of the beach rocks and local tide change were measured by using a Nikon Laser Level or Nikon Total Station. The sample materials collected from the three islands for ${ }^{14} \mathrm{C}$ dating were fossil shells and coral samples embedded in the beach rocks otherwise calcarenite or calcirudite. They were ${ }^{14} \mathrm{C}$ dated by the author at the Radiocarbon Dating Laboratory of Nihon University.

The isotopic fractionations of 41 beach rock samples were measured by Dr Toshio Nakamura, Professor of Nagoya University, and Mr Shigeru Ito and Mr Tomohiro Ohkawa, Systems Engineering Department of Marubun Corporation, Tokyo. Professor Nakamura analyzed 18 beach rock samples collected from Iriomote Island and Ishigaki Islands using MAT-252, while Mr Ito and Mr Ohkawa analyzed 19 beach rock samples collected from Miyako Island and 4 beach rock samples collected from Ishigaki Island using Optima of College of Humanities and Sciences, Nihon University.

(C) 2001 by the Arizona Board of Regents on behalf of the University of Arizona RadiocaRBON, Vol 43, Nr 2B, 2001, p 887-898

Proceedings of the 17 th International ${ }^{14} \mathrm{C}$ Conference, edited by I Carmi and E Boaretto 

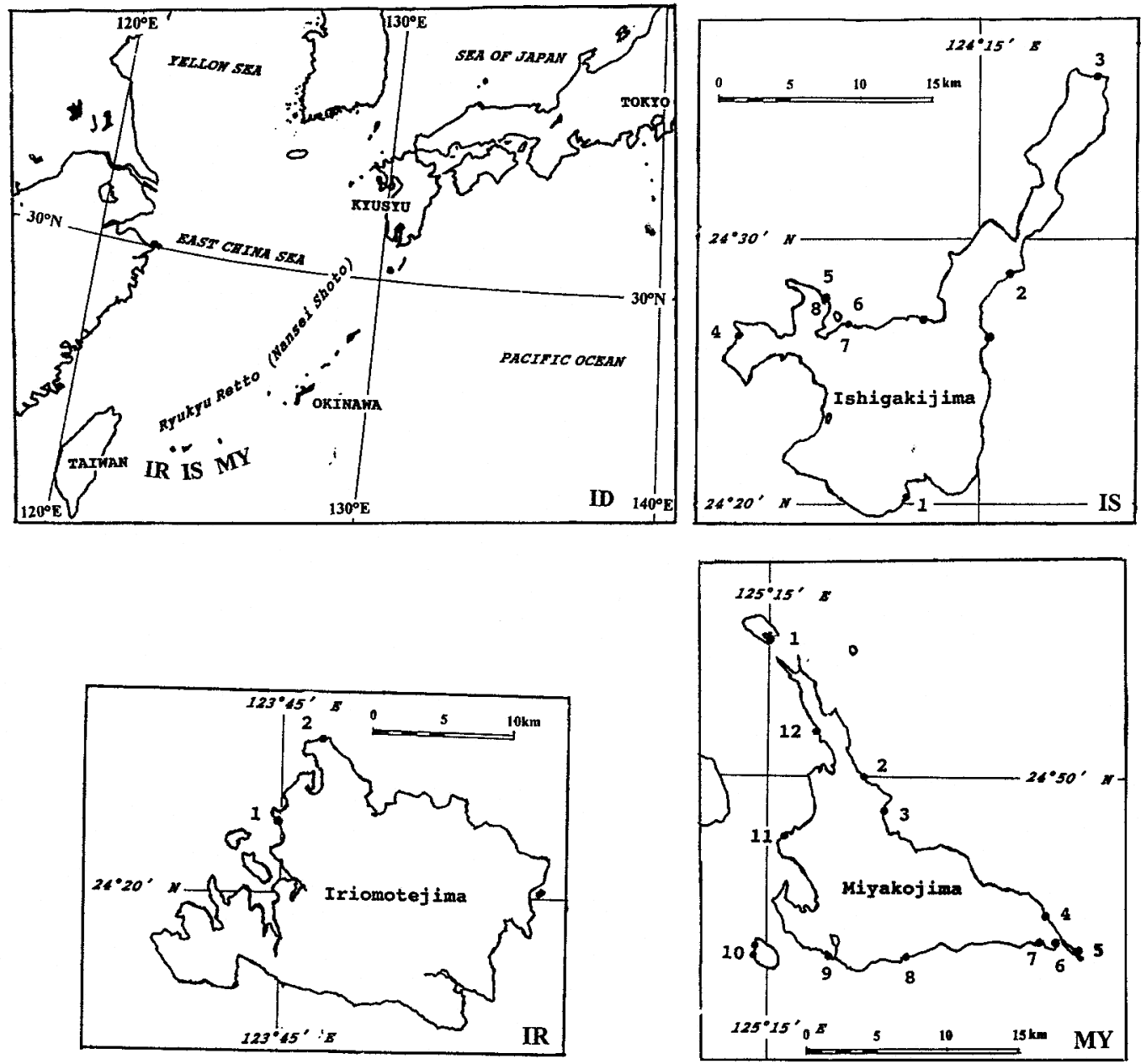

Figure 1 Location map of the surveyed area. ID: General location of the surveyed islands, IR: Iriomote Island, IS: Ishigaki Island, MY: Miyako Island. Figures on each map indicate the sites of sample collections and correspond to the figures shown in Table 1.

\section{DESCRIPTIONS OF SAMPLING SITES AND RESULTS OF RADIOCARBON DATINGS}

\section{Samples Collected from Iriomote Island}

Iriomote Island is situated at $24^{\circ} 20^{\prime} \mathrm{N}$ and $123^{\circ} 50^{\prime} \mathrm{E}$ (Figure 1), forming a rectangular area of $20 \mathrm{~km}$ per side, with an area of $289 \mathrm{~km}^{2}$. The highest peak of the island is Mt Komi (470 m asl) situated in the eastern part of the island. The island consists mainly of dissected highlands of around $400 \mathrm{~m}$ asl, considered to be a peneplain (Kawana 1988). High sea cliffs whose heights reach about 200$300 \mathrm{~m}$ asl develop along the west and south coasts. The bedrocks are the Paleozoic overlay the Miocene Yaeyama Formation and the Pleistocene Ryukyu limestone.

The development of beach rock is limited to small north and northwest sandy beaches where 6 beach rock samples were collected by the author from 30 April to 1 May 1999 (Figure 1, IR). They consist of one coral sample, two shell samples, and the rest calcirudite (or calcarenite). The beach rock 
observed at Soya (Figure 1, IR-1) was situated within the range of the intertidal zone, but its distribution was limited to a very small area. It is now impossible to reconstruct its original landform and to measure its length, width and inclination, as it has completely lost its original landform. While at Hoshizuna beach (Figure 1, IR-2), its length, width and inclination were about $40 \mathrm{~m}, 5-6 \mathrm{~m}$, and approximately 4 degrees seaward, respectively. The upper part of the beach rock has obviously emerged and is undergoing wave erosion. The characteristics of each beach rock in relation to elevation, length, width, inclination and ${ }^{14} \mathrm{C}$ dates are shown in Table $1 \mathrm{~A}$ and reported by the author (Omoto 2001).

\section{Samples Collected from Ishigaki Island}

Ishigaki Island is situated about $20 \mathrm{~km}$ east of Iriomote Island, at $24^{\circ} 25^{\prime} \mathrm{N}$ and $124^{\circ} 11^{\prime} \mathrm{E}$ (Figure 1), with an area of $222 \mathrm{~km}^{2}$. Between Ishigaki Island and Iriomote Island the largest reef flat in The Nansei Islands has emerged with a length of $20 \mathrm{~km}$ and a width of $15 \mathrm{~km}$. To the northeast of the island, Hirakubo Peninsula stretches approximately $20 \mathrm{~km}$ in length, and divides itself into two enbayments, while to the west Yarabe Peninsula stretches approximately $5 \mathrm{~km}$. The northern half of the island is characterized by dissected mountains having an elevation of approximately $400 \mathrm{~m}$ asl. The marine terrace surface of $80 \mathrm{~m}$ asl is restricted to the center of the island. The highest peak of the island is Mt Omoto (520 m asl), which is situated in the northern mountain area. The basement rocks are the Paleozoic and granite (intrusion rock) overlaying the Miocene Yaeyama Formation and the Pleistocene Ryukyu limestone.

The beach rocks were frequently observed within the range of the intertidal zone on many sandy beaches surrounding the island (Figure 1. IS). But at Loc. 1 and 5, they have obviously emerged. The length of the beach rocks was between $10 \mathrm{~m}$ and $200 \mathrm{~m}$, and their width was between $3 \mathrm{~m}$ and $17 \mathrm{~m}$. The seaward dips of the beach rocks were between 4 and 8 degrees. Twelve samples were collected by the author from March 18 to March 20, 1999, consisting of 4 coral samples, 3 shell samples, and 5 calcirudite (or calcarenite) samples. Characteristics of each beach rock and the results of ${ }^{14} \mathrm{C}$ dating are also shown in Table 1B.

\section{Samples Collected from Miyako Island}

Miyako Island is situated approximately $120 \mathrm{~km}$ to the east of Ishigaki Island, at $24^{\circ} 46^{\prime} \mathrm{N}$ and $125^{\circ} 20^{\prime} \mathrm{E}$, forming a triangular form with an area of $158 \mathrm{~km}^{2}$. The geology of the island consists of the Pliocene Shimajiri Formation, the Pleistocene Ryukyu limestone, and elevated coral reef sediments.

The highest peak is Mt Noharadake (108.5 m asl) in the center of the island. On the east coast, there is a straight bluff that stretches from northwest to southeast for more than $20 \mathrm{~km}$. Several narrow and low relief hilly lands run parallel to the east coast and the island inclines obviously from east to west. The landform is characterized by a flat, elevated terrace. These landforms resemble the small scale of cuesta ${ }^{1}$ topography.

Kawana and Pirazzoli (1984) determined the distribution of the beach rocks based on the interpretation of aerial photographs and confirmed 25 sites of beach rock distributions in their field survey. They collected four shell samples from the island, and reported their ${ }^{14} \mathrm{C}$ dates (shown with Lab code $\mathrm{N}$ in Table 1).

\footnotetext{
${ }^{1}$ A structural plain, so tilted that it has a perceptibly sloping surface
} 
Table 1 Radiocarbon dates of the beach rock samples collected from Iriomote Island, Ishigaki Island, and Miyako Island

\begin{tabular}{|c|c|c|c|c|c|c|c|}
\hline $\begin{array}{l}\text { Location number } \\
\text { latitude (N) } \\
\text { longitude (E) }\end{array}$ & $\begin{array}{l}\text { Elevation } \\
(\mathrm{m} \text { asl })\end{array}$ & Sample material & Lab nr & $\begin{array}{l}{ }^{14} \mathrm{C} \text { age } \\
\text { (conv. BP) }\end{array}$ & $\begin{array}{c}\delta^{13} \mathrm{C} \% \% \\
\mathrm{PDB}\end{array}$ & $\begin{array}{l}{ }^{14} \mathrm{C} \text { age }(\mathrm{BP}) \\
\text { (corrected) }\end{array}$ & $\begin{array}{l}\text { Beach rock } \\
\text { length }(\mathrm{m}) \text {; } \\
\text { width }(\mathrm{m}) ; \\
\text { inclination }(\mathrm{deg})\end{array}$ \\
\hline $\begin{array}{l}\text { A. Iriomote Island } \\
1 \quad 24^{\circ} 23^{\prime} 14^{\prime \prime} \\
123^{\circ} 44^{\prime} 49^{\prime \prime}\end{array}$ & -0.3 & Calcirudite & NU-1170 & $2890 \pm 75$ & 8.40 & $3120 \pm 75$ & \\
\hline $\begin{array}{l}224^{\circ} 26^{\prime} 12^{\prime \prime} \\
123^{\circ} 46^{\prime} 41^{\prime \prime}\end{array}$ & 0.6 & Calcirudite & NU-1165 & $3330 \pm 75$ & 5.57 & $3520 \pm 75$ & $40 ; 5-6 ; 4$ \\
\hline $\begin{array}{l}24^{\circ} 26^{\prime} 12^{\prime \prime} \\
123^{\circ} 46^{\prime} 41^{\prime \prime}\end{array}$ & 0.5 & Goniastrea sp. & NU-1166 & $3860 \pm 80$ & 2.1 & $3960 \pm 80$ & \\
\hline $\begin{array}{l}24^{\circ} 26^{\prime} 12^{\prime \prime} \\
123^{\circ} 46^{\prime} 41^{\prime \prime}\end{array}$ & 1.4 & $\begin{array}{l}\text { Tridacna } \\
\text { squamosa }\end{array}$ & NU-1167 & $3400 \pm 85$ & 3.5 & $3530 \pm 85$ & \\
\hline $\begin{array}{l}24^{\circ} 26^{\prime} 12^{\prime \prime} \\
123^{\circ} 46^{\prime} 41^{\prime \prime}\end{array}$ & 1.6 & $\begin{array}{l}\text { Tridacna } \\
\text { squamosa }\end{array}$ & NU-1168 & $3220 \pm 70$ & 8.37 & $3430 \pm 70$ & \\
\hline $\begin{array}{l}24^{\circ} 26^{\prime} 12^{\prime \prime} \\
123^{\circ} 46^{\prime} 41^{\prime \prime}\end{array}$ & 1.3 & Calcarenite & NU-1169 & $3440 \pm 80$ & 2.42 & $3530 \pm 80$ & \\
\hline $\begin{array}{l}\text { B. Ishigaki Island } \\
1 \quad 24^{\circ} 20^{\prime} 29^{\prime \prime} \\
124^{\circ} 11^{\prime} 52^{\prime \prime}\end{array}$ & 1.6 & Cyphastrea sp. & NU-1147 & $1640 \pm 65$ & 0.59 & $1700 \pm 65$ & \\
\hline $\begin{array}{l}24^{\circ} 20^{\prime} 29^{\prime \prime} \\
124^{\circ} 11^{\prime} 52^{\prime \prime}\end{array}$ & 1.7 & Goniastrea sp. & NU-1148 & $1780 \pm 85$ & 1.86 & $1860 \pm 85$ & \\
\hline $\begin{array}{l}24^{\circ} 20^{\prime} 29^{\prime \prime} \\
124^{\circ} 11^{\prime} 52^{\prime \prime}\end{array}$ & 0.7 & Goniastrea sp. & NU-1149 & $1940 \pm 65$ & 0.76 & $2000 \pm 65$ & \\
\hline $\begin{array}{c}2 \quad 24^{\circ} 29^{\prime} 12^{\prime \prime} \\
124^{\circ} 16^{\prime} 29^{\prime \prime}\end{array}$ & 0.2 & Goniastrea sp. & NU-1150 & $460 \pm 65$ & 1.50 & $520 \pm 65$ & $200 ; 5 ; 7$ \\
\hline $\begin{array}{l}24^{\circ} 29^{\prime} 12^{\prime \prime} \\
124^{\circ} 16^{\prime} 29^{\prime \prime}\end{array}$ & 0.2 & Calcirudite & NU-1151 & $1090 \pm 65$ & 7.86 & $1290 \pm 65$ & $200 ; 5 ; 7$ \\
\hline $\begin{array}{l}3 \quad 4^{\circ} 36^{\prime} 23^{\prime \prime} \\
124^{\circ} 19^{\prime} 55^{\prime \prime}\end{array}$ & \pm 0 & Polites sp. & NU-1152 & $880 \pm 65$ & 4.60 & $1000 \pm 65$ & $10 ; 8-15 ;-$ \\
\hline $\begin{array}{l}24^{\circ} 36^{\prime} 23^{\prime \prime} \\
124^{\circ} 16^{\prime} 29^{\prime \prime}\end{array}$ & \pm 0 & Calcarenite & NU-1153 & $1270 \pm 65$ & 7.03 & $1450 \pm 65$ & $10 ; 8-15 ;-$ \\
\hline $\begin{array}{l}4 \quad 24^{\circ} 26^{\prime} 46^{\prime \prime} \\
124^{\circ} 04^{\prime} 45^{\prime \prime}\end{array}$ & -0.3 & $\begin{array}{l}\text { Tridacna } \\
\text { squamosa }\end{array}$ & NU-1154 & $910 \pm 65$ & 6.11 & $1080 \pm 65$ & $10 ; 3 ; 8$ \\
\hline $\begin{array}{l}24^{\circ} 26^{\prime} 46^{\prime \prime} \\
124^{\circ} 04^{\prime} 45^{\prime \prime}\end{array}$ & -0.3 & Cyphastrea sp. & NU-1155 & $810 \pm 65$ & 0.46 & $850 \pm 65$ & $10 ; 3 ; 8$ \\
\hline $\begin{array}{r}24^{\circ} 26^{\prime} 46^{\prime \prime} \\
124^{\circ} 04^{\prime} 45^{\prime \prime}\end{array}$ & -0.2 & Calcirudite & NU-1156 & $1180 \pm 65$ & 7.16 & $1370 \pm 65$ & $10 ; 3 ; 8$ \\
\hline $\begin{array}{l}5 \quad 24^{\circ} 28^{\prime} 26^{\prime \prime} \\
124^{\circ} 08^{\prime} 10^{\prime \prime}\end{array}$ & 0.8 & $\begin{array}{l}\text { Tridacna } \\
\text { squamosa }\end{array}$ & NU-1157 & $1120 \pm 65$ & 8.63 & $1330 \pm 65$ & $-; 15 ; 7$ \\
\hline $\begin{array}{l}24^{\circ} 28^{\prime} 26^{\prime \prime} \\
124^{\circ} 08^{\prime} 10^{\prime \prime}\end{array}$ & 0.8 & Goniastrea sp. & NU-1158 & $1380 \pm 70$ & 5.24 & $1520 \pm 70$ & \\
\hline $\begin{array}{l}24^{\circ} 28^{\prime} 25^{\prime \prime} \\
124^{\circ} 08^{\prime} 10^{\prime \prime}\end{array}$ & 0.5 & Calcarenite & NU-1159 & $1690 \pm 65$ & 9.40 & $1920 \pm 65$ & \\
\hline $\begin{array}{l}24^{\circ} 28^{\prime} 25^{\prime \prime} \\
124^{\circ} 08^{\prime} 10^{\prime \prime}\end{array}$ & 0.1 & Carcirudite & NU-1160 & $1970 \pm 95$ & 8.79 & $2270 \pm 95$ & \\
\hline
\end{tabular}


Table 1 Radiocarbon dates of the beach rock samples collected from Iriomote Island, Ishigaki Island, and Miyako Island (Continued)

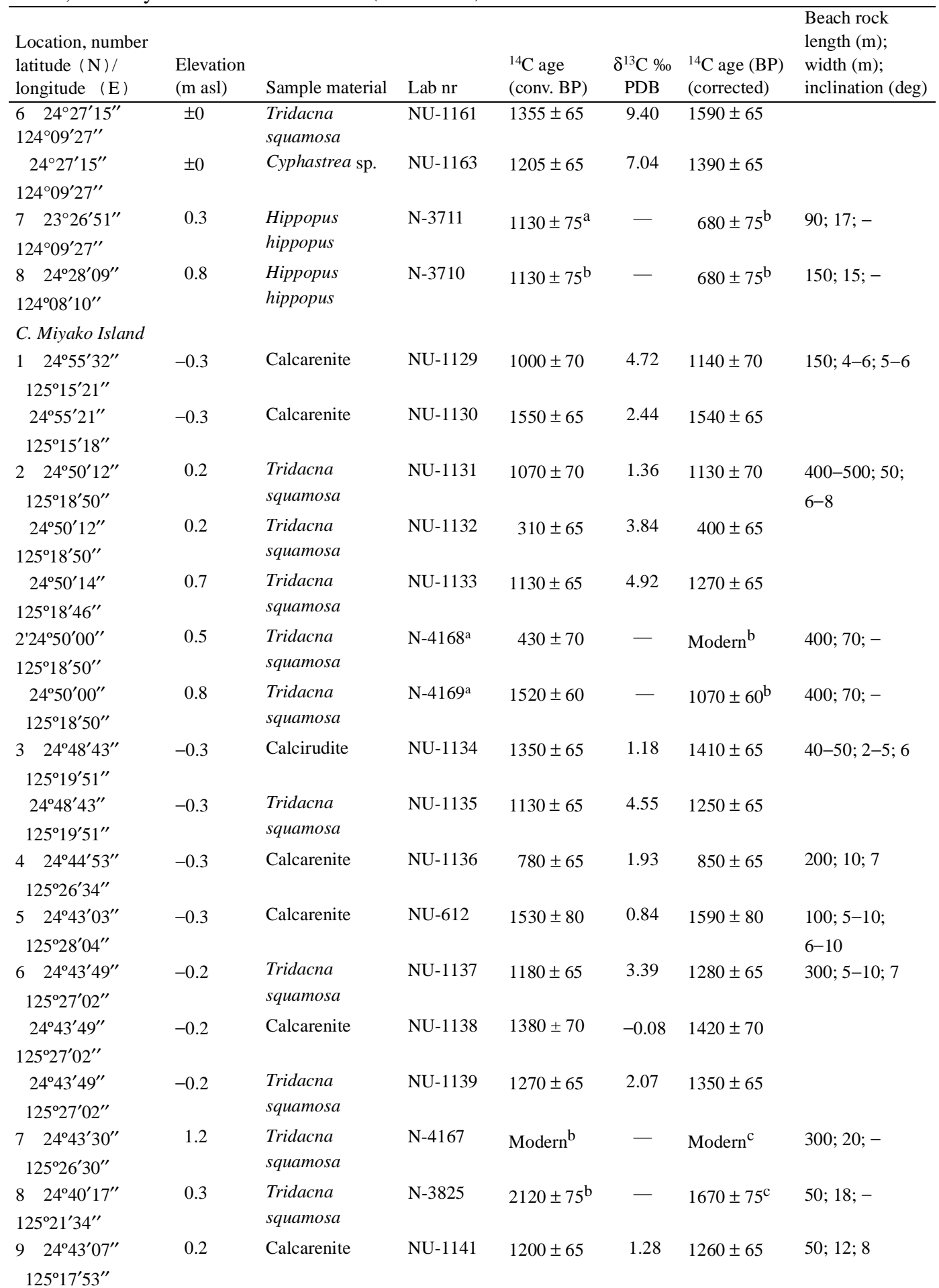


Table 1 Radiocarbon dates of the beach rock samples collected from Iriomote Island, Ishigaki Island, and Miyako Island (Continued)

\begin{tabular}{|c|c|c|c|c|c|c|c|}
\hline $\begin{array}{l}\text { Location, number } \\
\text { latitude (N)/ } \\
\text { longitude (E) }\end{array}$ & $\begin{array}{l}\text { Elevation } \\
\text { (m asl) }\end{array}$ & Sample material & Lab nr & $\begin{array}{l}{ }^{14} \mathrm{C} \text { age } \\
\text { (conv. BP) }\end{array}$ & $\begin{array}{c}\delta^{13} \mathrm{C} \% \circ \\
\mathrm{PDB}\end{array}$ & $\begin{array}{l}{ }^{14} \mathrm{C} \text { age }(\mathrm{BP}) \\
\text { (corrected) }\end{array}$ & $\begin{array}{l}\text { Beach rock } \\
\text { length }(\mathrm{m}) ; \\
\text { width }(\mathrm{m}) ; \\
\text { inclination }(\mathrm{deg})\end{array}$ \\
\hline $24^{\circ} 43^{\prime} 07^{\prime \prime}$ & 0.2 & Polites sp. & NU-1142 & $1950 \pm 70$ & 0.78 & $2010 \pm 70$ & \\
\hline \multicolumn{8}{|l|}{$125^{\circ} 17^{\prime} 53^{\prime \prime}$} \\
\hline $10 \quad 24^{\circ} 43^{\prime} 32^{\prime \prime}$ & -0.3 & Calcarenite & NU-1125 & $3420 \pm 75$ & 2.09 & $3530 \pm 75$ & $2-5 ; 2-3 ; 5$ \\
\hline \multicolumn{8}{|l|}{$125^{\circ} 14^{\prime} 24^{\prime \prime}$} \\
\hline $24^{\circ} 43^{\prime} 27^{\prime \prime}$ & -0.3 & Goniastrea sp. & NU-1126 & $3530 \pm 80$ & 2.66 & $3640 \pm 80$ & \\
\hline \multicolumn{8}{|l|}{$125^{\circ} 14^{\prime} 23^{\prime \prime}$} \\
\hline $24^{\circ} 43^{\prime} 27^{\prime \prime}$ & $1.8^{\mathrm{c}}$ & Tridacna & NU-1127 & $3100 \pm 75$ & 5.41 & $3270 \pm 75$ & \\
\hline $125^{\circ} 14^{\prime} 27^{\prime \prime}$ & & squamosa & & & & & \\
\hline $1124^{\circ} 47^{\prime} 43^{\prime \prime}$ & -0.2 & Carcirudite & NU-1140 & $1460 \pm 65$ & 1.75 & $1530 \pm 65$ & $15 ; 4-5 ; 5$ \\
\hline \multicolumn{8}{|l|}{$125^{\circ} 15^{\prime} 38^{\prime \prime}$} \\
\hline $1224^{\circ} 51^{\prime} 11^{\prime \prime}$ & -0.2 & Goniastrea sp. & NU-1128 & $2590 \pm 75$ & 0.56 & $2650 \pm 75$ & $50 ; 10 ; 8$ \\
\hline $125^{\circ} 27^{\prime} 31^{\prime \prime}$ & & & & & & & \\
\hline
\end{tabular}

Most of the beach rocks were observed within the range of the intertidal zone on the sandy beaches surrounding the island. However at Loc. 3 (Figure 1, MY-3) the beach rocks have obviously emerged (Figure 2; Omoto 1999b). The maximum length of the beach rocks reach $500 \mathrm{~m}$ and their width reach $70 \mathrm{~m}$. The seaward dips of the beach rocks are between 5 and 10 degrees. These beach rocks develop very well surrounding the island.

The author collected 19 beach rock samples from 12 sites (Figure 1, MY) between 26 and 28 December 1993, and between 28 and 30 December 1998. They are 2 coral samples, 7 shell samples, and 10 calcirudite (or calcarenite) samples. The characteristics of each beach rock with respect to elevation, length, width, inclination, and ${ }^{14} \mathrm{C}$ dates were reported by the author (Omoto 1999b) and are also shown in Table 1C.

\section{Isotopic Fractionations $\left(\delta^{13} \mathrm{C}\right)$ of Beach Rock Samples}

The results of isotopic fractionations $\left(\delta^{13} \mathrm{C}\right)$ for the 41 beach rock samples analyzed are expressed in Table 1 and Table 2. According to Table 1, the maximum $\delta^{13} \mathrm{C}$ value throughout 41 beach rock samples was $+9.40 \%$ o (calcarenite and Tridacna sequamosa samples) and the minimum was $-0.08 \%$ o (calcarenite sample). The isotopic fractionations among four kinds of sample materials indicated different values. That is, the value of $\delta^{13} \mathrm{C}$ for the calcirudite samples ranged from $8.79 \%$ o to $1.18 \%$, and their mean value was $5.83 \%$. While the value of $\delta^{13} \mathrm{C}$ for the calcarenite samples ranged from $9.40 \%$ to $-0.08 \%$ and their mean value was $3.21 \%$. The value of $\delta^{13} \mathrm{C}$ for Tridacna sequamosa samples ranged from $9.40 \%$ o to $1.36 \%$, and their mean value was $5.13 \%$. While the value of $\delta^{13} \mathrm{C}$ for the coral samples ranged from $7.04 \%$ o to $0.46 \%$ and their mean value was $2.35 \%$ o.

At Iriomote Island, 6 beach rock samples were analyzed. The maximum, minimum and mean $\delta^{13} \mathrm{C}$ values were $8.40 \%$ (calcirudite), $2.10 \%$ (Goniastrea), and 5.06\%, respectively. The mean $\delta^{13} \mathrm{C}$ val- 


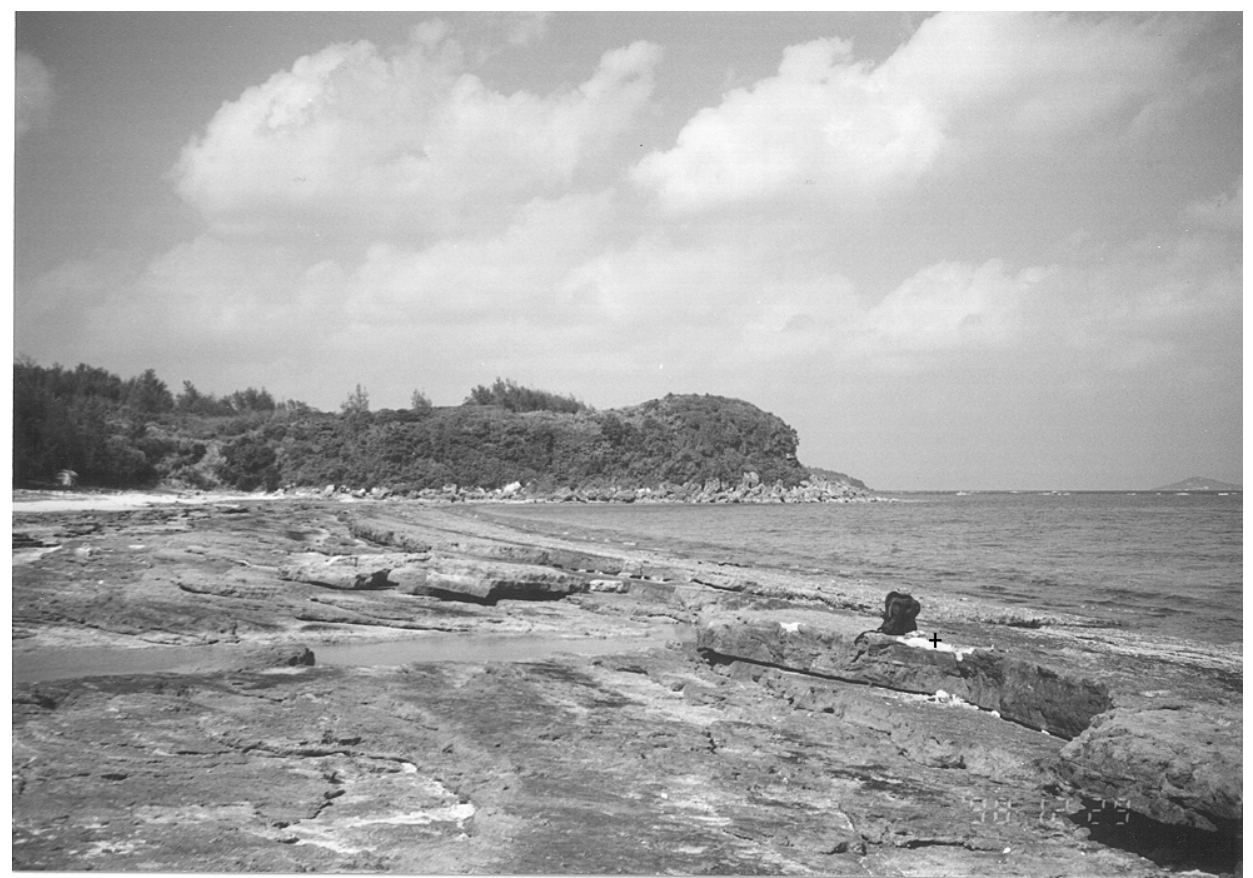

Figure 2 Beach rocks observed on the east coast of Miyako Island (Loc.3). The + mark in right side of the photograph indicates a site of sampling.

Table 2 Isotopic fractionations $\left(\delta^{13} \mathrm{C}\right)$ of beach rock samples

\begin{tabular}{lllll}
\hline Locality & Calcirudite & Calcarenite & Shell & Coral \\
\hline Iriomote Island & 5.57 & 2.42 & 3.50 & 2.10 \\
$\mathrm{~m}=5.06$ & 8.40 & & 8.37 & \\
Ishigaki Island & 7.16 & 7.03 & $\mathrm{~m}=5.93$ & \\
& 7.86 & 9.40 & 8.11 & 0.46 \\
& 8.79 & & 9.40 & 0.59 \\
& & & & 0.76 \\
& & & & 1.50 \\
& & & & 4.60 \\
$\mathrm{~m}=5.40$ & $\mathrm{~m}=7.94$ & $\mathrm{~m}=8.21$ & $\mathrm{~m}=8.05$ & 7.04 \\
Miyako Island & 1.18 & -0.08 & 1.36 & 0.56 \\
& 1.75 & 0.84 & 2.07 & 0.78 \\
& & 1.28 & 3.39 & 2.66 \\
& & 1.93 & 3.84 & \\
& & 2.09 & 4.55 & \\
Total sample & 7 & 4.44 & 4.92 & \\
Maximum & 8.79 & 1.42 & $\mathrm{~m}=3.65$ & $\mathrm{~m}=1.33$ \\
Minimum & 1.18 & 3.21 & 12 & 12 \\
Mean & 5.83 & 3.21 & 1.36 & 0.46 \\
\hline
\end{tabular}


ues of the calcirudite $(6.98 \%$ ) and Tridacna sequamosa samples $(5.93 \%$ ) seem to coincide, as do the mean $\delta^{13} \mathrm{C}$ value for the calcarenite $(2.42 \%$ ) and the coral samples $(2.10 \%)$.

At Ishigaki Island 16 beach rock samples were analyzed. The maximum, minimum and mean $\delta^{13} \mathrm{C}$ values were $9.40 \%$ (calcarenite and Tridacna sequamosa samples), 0.46\% (Cyphastrea sp.), and $5.40 \%$ respectively. The mean $\delta^{13} \mathrm{C}$ value among the calcirudite $(7.94 \%$ ), calcarenite $(8.21 \%$ ) and Tridacna sequamosa $(8.05 \%$ o samples coincide with each other, however they differ from the mean $\delta^{13} \mathrm{C}$ value for the coral samples $(2.77 \%$ ) .

At Miyako Island 19 beach rock samples were analyzed. The $\delta^{13} \mathrm{C}$ values of maximum, minimum and mean were $5.40 \%$ (Tridacna sequamosa), $-0.08 \%$ (calcarenite) and $2.40 \%$, respectively. The mean $\delta^{13} \mathrm{C}$ value among the calcirudite $(1.47 \%$ ) , calcarenite $(1.89 \%$ ) and coral samples $(1.33 \%$ ) coincide with each other, however they also differ from the mean $\delta^{13} \mathrm{C}$ value for the Tridacna sequamosa samples (3.65\%o).

The mean $\delta^{13} \mathrm{C}$ value obtained from Iriomote Island $(5.06 \%$ ) and Ishigaki Island $(5.40 \%)$ coincide, however they differ significantly from the mean $\delta^{13} \mathrm{C}$ value obtained from Miyako Island $(2.40 \%$ ). The above-described data are summarized and shown in Table 2.

\section{DISCUSSION}

\section{Correction of Radiocarbon Ages}

Prior to discussions, the author corrected ${ }^{14} \mathrm{C}$ dates based on the figures for isotopic fractionations $\left(\delta^{13} \mathrm{C}\right)$ of each sample and ocean reservoir effect.

The figure for the ocean reservoir effect used in this paper is $450 \mathrm{yr}$ based on TH-104 (Omoto 1976) which was determined using modern coral samples (Acropora sp.) collected from Naha, Okinawa Prefecture, before World War II by Dr Shoshiro Hanzawa, Emeritus Professor of Tohoku University. As there was no data for the ocean reservoir effect in the surveyed area, the author used this figure instead of the mean correction value for the world's oceans. According to Stuiver and Braziunas (1993) the average figure of the reservoir effect for the world's oceans is estimated to be $400 \mathrm{yr}$. Therefore, it seems a satisfactory and compatible value compared with the generally accepted figure (Stuiver and Braziunas 1993) for the ocean reservoir effect.

\section{Variations of Isotopic Fractionations $\left(\delta^{13} C\right)$}

Figure 3 indicates a relationship between $\delta^{13} \mathrm{C}$ values and ${ }^{14} \mathrm{C}$ ages obtained from three islands surveyed. It indicates three or four parts of concentrations equivalent to the data set of each island. The left spheroid represents the entire data of Iriomote Island, while the large right oval represents the entire data of Ishigaki Island. The data of Miyako Island are divided into two spheroids shown in the left and right halves of Figure 3. These distributions and/or patterns indicate a paleoenvironment of each island where and when the beach rocks have been formed. The inclinations of the lines of apsides for Iriomote Island and Miyako Island run parallel except for the younger dates. But most of the data obtained from Ishigaki Island scatter in a wide area and it is difficult to find regularity. It is noticeable that there exist only data indicating $2650 \mathrm{BP}$ between $2800 \mathrm{BP}$ and $1950 \mathrm{BP}$. The change of ocean currents (Kuro Shio) or climatic changes might have occurred in this period. The gravity centers of each spheroid indicate the mean value of the isotopic fractionations. The gravity center of Miyako Island indicates lower $\delta^{13} \mathrm{C}$ values compared with those of the other two islands. The difference might be caused by the geographic location of the island, that is Miyako Island is located in 


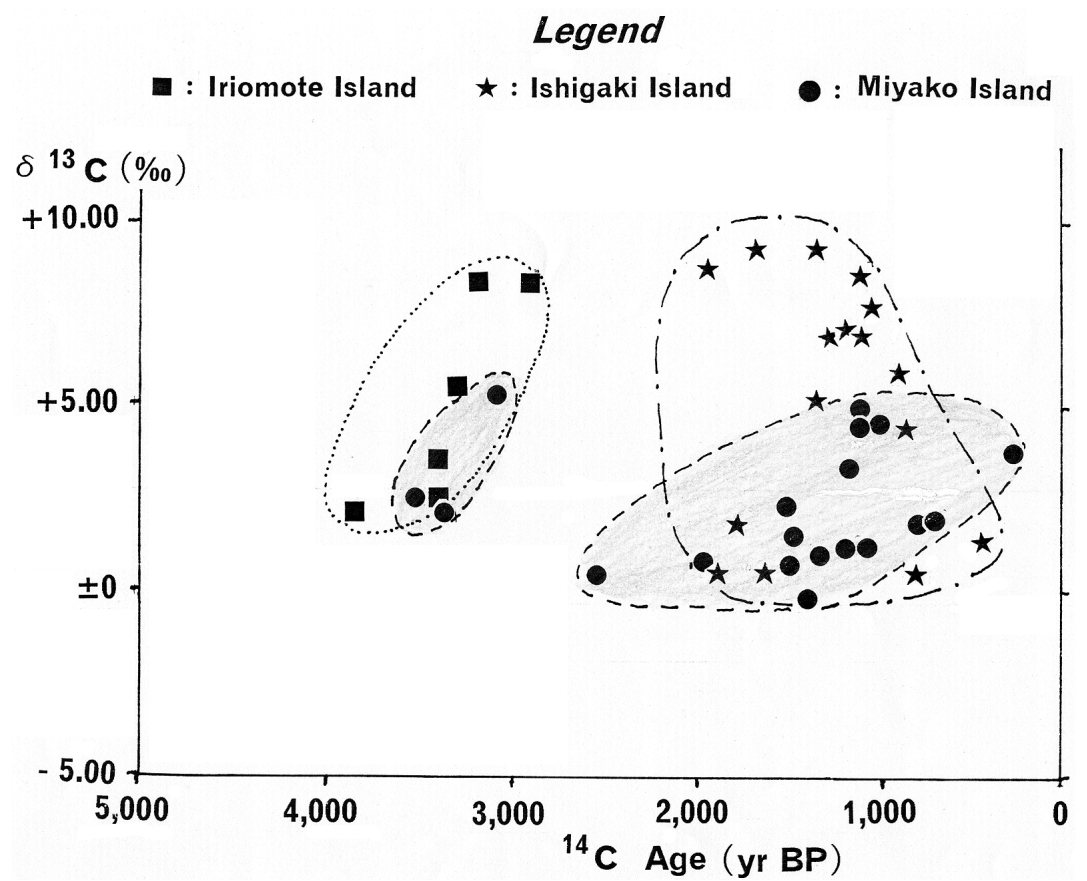

Figure 3 Relationship between $\delta^{13} \mathrm{C}$ values and ${ }^{14} \mathrm{C}$ ages obtained from Iriiomote, Ishigaki, and Miyako Islands

higher latitudes than other two islands, otherwise it is located on the edge of the Eurasian Plate where upwelling might have occurred.

Although the different materials were collected from the same locality and horizon, the result of ${ }^{14} \mathrm{C}$ dating brought diversity in ages, except Loc. 2 of Iriomote Island where the four dates coincided. But in Loc. 2, 3, and 5 at Ishigaki Island, and Loc. 1, 2, and 9 at Miyako Island, the corrected ages did not coincide within the range of $\pm 2 \sigma$ error.

\section{Origin of Calcium Carbonate}

The value of isotopic fractionation $\left(\delta^{13} \mathrm{C}\right)$ for marine carbonates and organisms has been reported by Vogel and Ehhalt (1963), Stuiver and Polach (1977), Gey and Schleicher (1990), and Stuiver and Braziunas (1993). According to Geyh and Schleicher (1990) the value is within the range of $\pm 2 \%$. The maximum figure of isotopic fractionations $\left(\delta^{13} \mathrm{C}\right)$ for the beach rocks collected from the surveyed area showed $+9.40 \%$ (Table 1 ). If the calcium carbonate of the beach rocks originated from seawater, the isotopic fractionation should be within the range of $\pm 2 \sigma$. However, maximum and mean $\delta^{13} \mathrm{C}$ values indicated a figure four times larger than those reported by the above-mentioned authors. The results suggest that the materials consisting of beach rocks were obviously affected by a different calcium carbonate origin, possibly provided when they were cemented in the intertidal zone.

Another possibility for the diversity is that the figure for the ocean reservoir effect in the late Holocene period might have been different from the modern standard. However, there is not enough $\delta^{13} \mathrm{C}$ data to speculate on the problem from a statistical point of view. Therefore it is also difficult to clarify the origin of the calcium carbonate in the beach rocks, and to demonstrate the figure for the 
past ocean reservoir effect. The author needs further $\delta^{13} \mathrm{C}$ data on the beach rocks in order to come up with an accurate answer.

\section{Formative Age of the Beach Rocks}

Kawana and Pirazzoli (1984) presumed that the ${ }^{14} \mathrm{C}$ age of Tridacna squamosa in the beach rocks collected from Miyako Island, about $120 \mathrm{~km}$ east of Ishigaki Island, was not much older than the formative age of the beach rocks. Strictly speaking, some time delay may exist between the formative age of beach rock and the measured ${ }^{14} \mathrm{C}$ age. That is, the materials used for ${ }^{14} \mathrm{C}$ dating were essentially marine carbonates and organisms. And they were carried from their original habitats to the intertidal zone by ocean waves, deposited on the beach, cemented with other beach sediments by calcium carbonate and then became beach rock.

The age of coral and shell samples from the beach rock indicates only the time of death of marine organisms, not the formative age of the beach rock. When we measured calcarenite or calcirude as a dating material, the calcium carbonate, which worked as an adhesive, might have derived its origin from underground water or seawater. If it was derived through the ground by underground water, especially on the island, which consisted of coral limestone, the measured age may indicate an older ${ }^{14} \mathrm{C}$ age rather than the true age. This is because the underground water might contain dead carbon originating in the limestone. In this case, it may be possible to distinguish the source of the calcium carbonate based on the values of isotopic fractionations $\left(\delta^{13} \mathrm{C}\right)$.

The beach rock samples were usually collected from the uppermost position (top layer). When the seaward width of the beach rock exceeds $20 \mathrm{~m}$, not only the topmost layer of the beach rock, but also the middle and landward specimens were collected to check the growth rate of the beach rock. According to Kawana and Pirazzoli (1984), the seaward growth was $4.2 \mathrm{~cm} / \mathrm{yr}$ at Miyako Island. While vertical growth rate at Aguni Island, in the center of The Nansei Islands was $0.15 \mathrm{~cm} / \mathrm{yr}$ (Omoto 1999a). The width of the beach rocks in the surveyed islands was usually shorter than $20 \mathrm{~m}$ and never exceeded $100 \mathrm{~m}$, nor did their thickness exceed $1 \mathrm{~m}$. These data suggest that the beach rocks have been cemented usually within a short period not exceeding $500 \mathrm{yr}$. The widest beach rocks occur at Miyako Island (Loc.2) where the width is approximately $70 \mathrm{~m}$ and the formation had a duration of about 1200 years.

The author has considered that even if the materials consisting of the beach rocks were different, the corrected ages whose materials were collected from the same horizon should indicate the same age within a range of error $\pm 2 \sigma$. To demonstrate this hypothesis the author collected different kinds of sample materials (i.e. calcirudite or calcarenite, coral, and shell samples) from each sampling site and horizon. But the corrected ages never coincided and the hypothesis could not be demonstrated.

${ }^{14} \mathrm{C}$ dates of beach rocks collected from the southern part of the Nansei Islands indicate that they were formed between around $4000 \mathrm{BP}$ and $400 \mathrm{BP}$. At Iriomote Island the beach rocks were formed at around $4000 \mathrm{BP}, 3500 \mathrm{BP}$, and $3100 \mathrm{BP}$, respectively. While at Ishigaki Island the beach rocks were formed at around $2300 \mathrm{BP}$, between $2000 \mathrm{BP}$ and $850 \mathrm{BP}$, and at around $500 \mathrm{BP}$, respectively. At Miyako Island the beach rocks were formed between $3600 \mathrm{BP}$ and $3300 \mathrm{BP}$, at around $2700 \mathrm{BP}$, at $2000 \mathrm{BP}$, between $1700 \mathrm{BP}$ and $900 \mathrm{BP}$, and at $400 \mathrm{BP}$, respectively. These dates indicate the formative periods and/or ages of the beach rocks in the surveyed islands.

\section{Late Holocene Sea-Level Change}

The well-developed marine terrace surfaces and the existence of notches are excellent indicators of the past sea level changes and/or uplifts. If their formative ages could be determined, we would be 
able to reconstruct the past sea level changes and/or uplifts by using their formative ages and elevations. The Holocene marine terrace surfaces develop poorly at Ishigaki Island and Iriomote Island although marine terrace surfaces develop at Miyako Island where they were formed during the Pleistocene. The notches developed well surrounding the islands, however no reliable ${ }^{14} \mathrm{C}$ ages indicating their formative ages were obtained. Based on the pieces of evidence in the surveyed area, the author could not find notable neotectonic upheaval throughout the Holocene period.

Therefore it is possible to estimate the late Holocene sea level changes in the southern part of The Nansei Islands based on the elevations and ${ }^{14} \mathrm{C}$ dates of beach rocks collected from the three islands. Almost all of the beach rocks observed in the surveyed area were situated within a range corresponding to the present intertidal zone. Based on these data the past sea level existed at a level similar to the present one, that is, it has maintained almost the same level as the present one since at least 4000 BP (Figure 4).
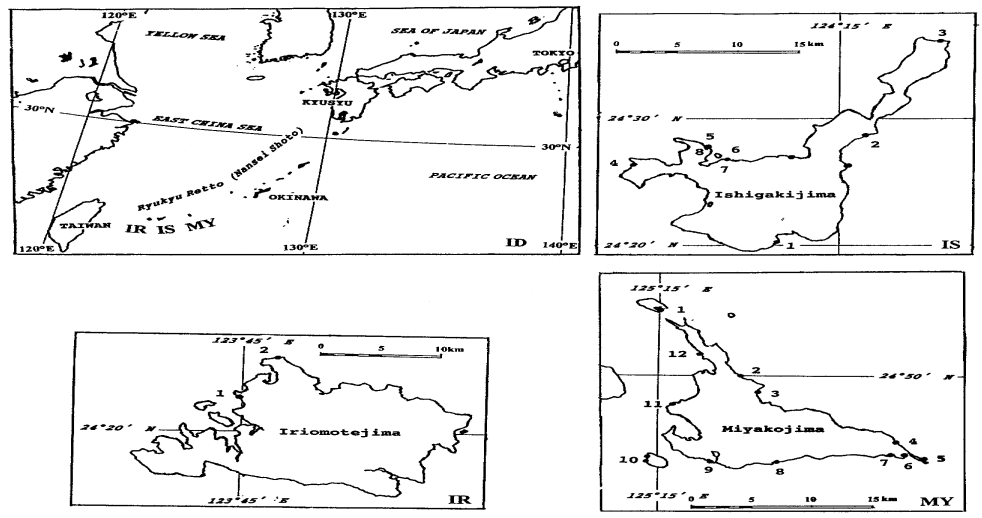

Figure 4 Late Holocene sea level change in the southern part of the Nansei Islands. The white circles indicate ${ }^{14} \mathrm{C}$ data reported by Kawana (1981) and Kawana and Pirazzoli (1984), while black circles are based on Table 1 .

\section{CONCLUSION}

The results of this study may be summarized as follows.

1. The beach rocks were formed within the range of the intertidal zone at approximately $4000 \mathrm{BP}$, $3500 \mathrm{BP}$, and $3100 \mathrm{BP}$ at Iriomote Island, and they were formed at Ishigaki Island at approximately $2300 \mathrm{BP}$, between $2000 \mathrm{BP}$ and $850 \mathrm{BP}$, and at approximately $500 \mathrm{BP}$, respectively. While at Miyako Island the beach rocks were formed between $3600 \mathrm{BP}$ and $3300 \mathrm{BP}$, at approximately $2700 \mathrm{BP}$, at $2000 \mathrm{BP}$, between $1700 \mathrm{BP}$ and $900 \mathrm{BP}$, and at $400 \mathrm{BP}$, respectively.

2. There is no evidence indicating prominent upheaval in the surveyed area throughout the Holocene Period. Therefore the elevations and ${ }^{14} \mathrm{C}$ ages of the beach rock samples would indicate past sea level changes. The late Holocene sea level has been similar to the present one since at least the past $4000 \mathrm{yr}$.

3. The figures for isotopic fractionations $\left(\delta^{13} \mathrm{C}\right)$ of beach rock samples were between $+9.40 \%$ and $-0.08 \%$. The average figures for calcirudite, calcarenite, coral and shell samples were $5.83 \%$, $3.21 \%, 2.35 \%$, and $5.13 \%$, respectively. 
4. Four kinds of materials consisting of beach rocks were collected from the same horizon to demonstrate the hypothesis that the ${ }^{14} \mathrm{C}$ age of beach rocks after isotopic corrections should indicate the same age within $\pm 2 \sigma$ error. But the corrected ${ }^{14} \mathrm{C}$ dates showed diversity in most places.

5. The maximum figure of $\delta^{13} \mathrm{C}$ obtained from the beach rock samples is four times larger than those reported previously. The difference of $\delta^{13} \mathrm{C}$ values among beach rocks demonstrates that beach rocks were evidently affected by a different origin of calcium carbonate, which possibly occurred when they were cemented.

6. Another possibility is that the figure for the past ocean reservoir effect might have been a different one when compared with those of modern standards.

To discuss precisely the origin of calcium carbonate and the cementing process of the beach rocks, and the past ocean reservoir effect, the author needs more data on $\delta^{13} \mathrm{C}$ values obtained from the beach rocks.

\section{ACKNOWLEDGMENTS}

I am grateful to Professor Toshio Nakamura of Nagoya University and Messrs. Shigeru Ito and Tomohiro Ohkawa, Systems Engineering Department of Marubun Corporation, Tokyo who measured $\delta^{13} \mathrm{C}$ of beach rock samples collected from Iriomote Island, Ishigaki Island and Miyako Island. Other thanks are given to those who helped me in the chemical analysis of ${ }^{14} \mathrm{C}$ dating: Miss Wakana Koreeda and Mrs Motoko Miyahara. Professor Motoharu Koba of Kansai University kindly identified coral samples. Professor Toshio Kawana of Ryukyu University provided me with useful comments on the beach rocks of the Nansei Islands. I would like to express my gratitude to Professor William D Patterson, Department of English Literature, College of Humanities and Sciences, Nihon University, for his suggestions and improvements of my English. Field surveys were supported by a Scientific Grant in Aid from the College of Humanities and Sciences, Nihon University.

\section{REFERENCES}

Geyh MA, Schleicher H. 1990. Absolute age determination. Springer-Verlag. $503 \mathrm{p}$.

Kawana T. 1981. Radiocarbon ages of the beach rocks on Okinawa, Miyako and Ishigaki Islands, the Ryukyus, Japan. Bulletin of College of Education University of the Ryukyus 25:245-9.

Kawana T, Pirazzoli PA. 1984. Late Holocene shorelines and sea level in Miyako Island, the Ryukyus, Japan. Geographical Review of Japan 57(Series B):135-41. In Japanese.

Kawana T. 1988. Geomorphology of the Ryukyus. Series of the Nature of Okinawa. Naha, Okinawa: Sinsei Tosyo Syuppan. 127 p. In Japanese.

Koba M. 1983. Late Holocene relative sea level changes and crustal deformation in the Ryukyu Island, Japan. Gekkan Chikyu 5(12):722-33. In Japanese.

Omoto K. 1976. Tohoku University Radiocarbon Measurements III. Science Reports of the Tohoku University 7th Series (Geography) 26(1):135-57.

Omoto K. 1999a. Radiocarbon ages of beachrock and fossil coral samples collected from Agunijima, southwestern part of Japan - chronological view on the Late Holocene sea level change of Agunijima. Annals of
The Geography, The Chiri Shiso 40(2):15-28. In Japanese.

Omoto K. 1999b. Radiocarbon dates of Beachrock samples collected from Miyakojima (Island), southern Ryukyu Islands. Preprint for Annual Meeting of The Japanese Coral Reef Society. 17 p. In Japanese.

Omoto K. 2001. Radiocarbon Ages of Beachrock Samples Collected from Iriomote Island, Southwestern Part of Japan. Annals of The Geography, The Chiri Shiso 42(1-2):17-30. In Japanese.

Ota Y. and Hori N. 1980. Late Quaternary tectonic movement of the Ryukyu Islands, Japan. Daiyonki Kenkyu (The Japanese Quaternary Research) 18:221-40. In Japanese.

Stuiver M, Polach HA. 1977. Discussion: reporting of ${ }^{14} \mathrm{C}$ data. Radiocarbon 19(3):355-63.

Stuiver M, Braziunas TF. 1993. Modeling atmospheric ${ }^{14} \mathrm{C}$ influences and ${ }^{14} \mathrm{C}$ ages of marine samples to 10,000 BC. Radiocarbon 35(1):137-89.

Vogel JC, Ehhalt D. 1963. The use of the carbon isotopes in groundwater studies. Radioisotope Ratios as Pollutant source and Behaviour Indicators. Vienna: IAEA. p 143-50. 